\title{
Two Renaissance Lives: Benvenuto Cellini and Teresa of Jesus
}

\section{YEMIN \\ CHAO}

Résumé: Le présent article examine les autobiographies de deux personnages renaissants, le premier un artiste séculaire, le second une religieuse contemplative. À travers les images dont chacun se sert pour se façonner, on peut apercevoir un engagement commun avec certains thèmes humanistes et religieux qui définissent l'époque. Bien que la Renaissance soit généralement abordée comme l'âge d'un classicisme revivifié et des tendances humanistes suscitées par ce dernier, il faut peut-être également considérer la lutte avec son héritage chrétien comme l'élément qui prête à la Renaissance son caractère distinct et particulièrement profond.

R envenuto Cellini's autobiography was composed between the years 1558 and 1566; it was begun, as he informs us, in the Florence of the High Renaissance, where he was born and to which he had returned after countless vicissitudes. He was fifty-eight and judged himself ripe for the undertaking, having satisfied his own criterion of being someone "who has to his credit what are or really seem great achievements." Teresa of Jesus began writing her life some years before 1562 , when she was forty-eight, and completed it in 1565 in the convent she had recently founded within the Spanish heart of the Counter-Reformation. Her desire in writing was that God "may be praised and magnified a little when men see how on a foul and stinking dunghill he has planted a garden of such sweet flowers."2

On the face of it, there seems little basis for a comparative study of two such lives. One person lived the volatile, creative and amoral life that has come to be regarded as a Renaissance type, while the other kept a noiseless 
tenor of pious and mysterious existence that seems an anachronistic survival from the Middle Ages. The facts that Cellini invoked the name and help of God at almost every turn in his life and that he claimed at the heart of his writings a revelation as spectacular as Teresa's have usually been ignored. The easiest modern stance is to regard Cellini's claims as nothing other than a pack of entertaining lies, Teresa's as subconscious delusions linked with psychosomatic disturbances. Yet to treat Cellini's visionary claims as amusing lies is to assume that he took his Catholicism, as well as his boasts, none too seriously. Neither assumption is tenable on a close reading. To regard Teresa as a type is to do injustice to the rich complexity of her awareness and experiences. To consider her a counter-revolutionary against the currents of the Renaissance is to ignore the way she was influenced by and contributed to the discovery and study of "Man."

Approaching the sixteenth century through fixed types and categories will only result in circular arguments. Beginning with specific individuals and how they saw themselves may yield surprising and corrective inductions. First, a preliminary question concerning "design and truth" in autobiographies needs to be tackled. There is a point of view that treats autobiography as a purely literary genre and assumes poetic licence about the self in such compositions. Its thesis is that sane and serious autobiographers lie as a matter of convention about the historical facts of their lives in the interest of ideal representation. The reason for reading them, then, is that, as Roy Pascal puts it, "[e]ven if what they tell us is not factually true, or only partly true, it always is true evidence of their personality." 3 Pascal's point is unobjectionable, but it is difficult to accept that the historical truth content of an autobiography is likely to be equal to that of a picaresque novel. Exaggerations and exclusions seem more likely than pure lies, and it is normal that an individual's private ordering of facts is audited by his public self. This will be taken as a fixed condition in the following enquiry. The study will proceed to analyse the two lives according to certain common motifs present in both texts and reveal what I believe to be an uncommon unity in their deep structure. The first part will show how both lives can be understood as fulfilling conventional conceptions of self attributed to the Renaissance despite the great disparity in chosen vocations. The second part will take the demonstration one step further and show how the modern model of a culture and counter-culture is rendered irrelevant by the fluid transitions between humanist and religious perceptions in these Renaissance lives. 


\section{Surveying Two Lives: Unlikely Affinities}

\section{i) The Life as Discoverer}

Cellini began his career, like Teresa, by running away from home. Setting out for Rome at nineteen, "the same age as the [sixteenth] century," as he noted, he had "cherished hopes of proving what sort of man [he was] from the work of [his] hands" (p. 33). In a short space he set his hand to every art within and beyond the goldsmith's craft, continually discovering new possibilities in working with various metals. He took pride in observing: "All the crafts I have mentioned are so different that if an artist is good at one of them and then turns to the others, he never succeeds in reaching the same standard as in the one he is perfect at. All the same I did everything I could to become expert in each one of them" (p. 52). Exploring his own capacity in working with clay and marble, he remarked that "the splendid Donatello" had failed to understand fully the qualities of the former and that even "the great Michelangelo" could not match his knowledge of the latter. For the casting of the bronze Perseus, he set himself new limits of difficulty in the form of the torso and had to design and build a furnace specially for the unprecedented high temperatures anticipated. His relish of praise from popes and kings for having surpassed antiquity defined the aspirations of his age. His main motivation, as he pointed out, had always been "a spirit of honest rivalry" (p. 51), but there is also sheer technical delight in finding out the frontiers of possibility with various media.

Linked to artistic explorations is Cellini's incessant journeying in search of optimal conditions and patronage for his craft. Continually at odds with the law, his way of living challenged the limits of social and legal acceptability. Proclaiming early on that he was "born free and meant to remain free" (p. 34), he suffered few trammels to his vital expression and love of excess in sentiment as in act. He was another Faustus dabbling in necromancy but surviving the conjuration of legions. The way down was to be complemented by the way up in his record of celestial sightings in his prison cell. His disclosure that he had read Dante and the way in which the bulging figures of the sun's disc in a vision resemble his relief etchings on medallions suggest that visual imagination might have been at work. How seriously he intended us to read the episode and its structural function will be considered below. Here we may simply note that he had aspired to gaze on the sun like Saint John the Divine, whose symbol was the eagle.

An ecstasy takes hold, according to Teresa, who is quoting from Deuteronomy 32:11, like a "powerful eagle, rising and bearing you up with it on 
its wings" (p. 136). Such an experience occurred as the culmination of the various stages of prayer that Teresa had spent her life discovering and defining. R. T. Petersson, in The Art of Ecstasy, has described her in terms that suggest her role as a spiritual scientist: "Teresa's strength lies in precise empirical observation, in a language very sensitively attuned to its subject, in her explanation of minute changes within the soul."4 Prayer was her craft, and in it she proved more comprehensive than almost any medieval mystic before her. Her journeys, unlike those of Cellini, were conducted within the states of an inner terrain; as she put it, "There is no need to climb up to Heaven, nor to go farther than to our own selves" (p. 308). Hailing tested experience, like Montaigne, as the only means to real knowledge but rejecting his resignation to nature, she sought by turning her back on one world to chart the territories of an unknown other. "So far as my desires went, they were always ambitious" (p. 90), she confessed. One may compare the strength of her longing for freedom to Cellini's: "O what a grand freedom it is, to look upon the need to live and behave according to the world's laws as a captivity" (p. 115). Her asceticism needs to be seen in this light.

What she discovered was that "one [could] see things with other eyes than those of the body" (p. 53) - in fact, through a sixth sense involving the transposition of the five senses. Transposed tactile and auditory images figured most prominently in her descriptions of the "soul's sensations," 5 and her visions were rarely visual. Unlike Cellini, who possessed a strong graphic imagination, Teresa confessed to being naturally weak in that faculty. She did experience vivid graphic revelations notwithstanding; still, her most usual mode was of an intimate Presence. Coupled with her discovery of the divine presence was, paradoxically, a discovery of the soul's natural condition. Its wretchedness she diagnosed in a divided psyche, where the intellect and imagination wage a bitter war against the will and the conflict is only partially resolved through four successive stages of prayer. These she likened to four different ways of drawing water to tend the garden of the soul. In her systematic approach, as in the earthiness of her language, she must rank among the earliest and most competent "psychoanalysts" of her age. Her first subject was herself. She was also an ethical analyst, since the discovery of the soul's treacherous depths drove her to the most painstaking examination of its minutest motive. Her extreme inner self-consciousness is hardly matched by Montaigne, the behaviourist who possessed an unassailable serenity of soul. 
ii) The Life as Courtier

Cellini did not think of himself as an artist solely; he was also the exemplary courtier, epitomizing sprezattura in all his alleged accomplishments. $\mathrm{He}$ refused to descend to the vulgarity of rating his own work and preferred to leave it to discriminating patrons, who would know enough to embellish praise with comparable substance. One patron (Duke Cosimo of Florence) who violated that understanding wound up in Cellini's record for posterity: "But not realising that this lord behaved more like a merchant than a duke, it was as a duke rather than merchant that I dealt with him" (p. 314). Indeed, the typical pattern he recorded was for his product to exceed all expectations but for rewards never to match promises, a situation that prompted him to "clear out" in response. Most frequently, malicious envy on the part of hangers-on was the cause of the detractions he suffered before kings, dukes and popes. Cellini, for his part, was no pacifist, for he returned back-stabbing with frontal thrusts of the stiletto, and perceived injustice was met with eloquent tongue-lashings, from which not even the Pope was exempt. Most potent of all arms was his talent. His record suggests that Bandinello, a rival sculptor, and not a few German and Parisian craftsmen, died of shame and exhaustion through trying to keep up with Cellini.

It is at the court of King Francis I that Cellini seemed to have found the perfect setting for his brilliance. Disheartened by jealous courtiers who were plotting to dislodge him, Cellini was asked by the king, "Who are you? What's your name?" (p. 257). Momentarily stunned, Cellini forgot what he had explained to us at the beginning about the meaning of his name: "You are welcome," his father had proclaimed at his delivery, with his expectations of a baby girl pleasantly confounded. Then the king reminded him: "Well if you're the Benvenuto I've heard of, act as you usually do - and I give you full permission" (p. 257). The king also paid liberally, but, what was more, Cellini felt that he was understood: "[His Majesty] saw that I was not the man to make a song and dance about it, but that the same day before you could bat an eyelid I would clear off without saying a word" (p. 293). In reciprocation, Cellini played the flatterer for once and dedicated his statue of Mars to the king as a representation of the royal valour. He was to cherish the fact that His Majesty had called him "mon ami" (p. 304).

In the end, however, he did clear out. His excuse was that he had to attend to his sister and her orphans. Primarily, perhaps, his departure had to do with the king's rebuke, which resembled that of Pope Clement before him. It was over the fact that Cellini consistently ignored his wishes and 
worked according to his own preferences. "Now you should be a little more obedient and less arrogant and headstrong" (p. 302), the king had told him.

In other respects, Cellini presents himself in his book according to the portrait of an accomplished courtier, such as might be found in Castiglione's guide. He takes pride in tracing his origin back through "men of mettle" (p. 17), enjoys the awe that his "military character and bearing" (p. 68) inspired, and makes constant references to his graceful but deadly accuracy with his harquebus. The profession of arms that Castiglione had made a prime requisite of a courtier was amply exemplified by a daredevil who almost single-handedly held out the Castel Sant'Angelo against the sack of Rome and who was a veteran of countless street skirmishes in peacetime. Yet he was a master, too, in the arts of peace. The musician that enchanted the pope, the poet who ranged through heaven and hell, the diplomat who acquitted himself with distinction before the emperor, the orator who struck terror into the hearts of magistrates and lawyers with blazing eloquence and stiletto, and, finally, the scholar and critic who offered new insight into the dark opening line of Canto 7 in Dante's Inferno - these were all met in one figure. Like a jeweller who sets off his diamond to full advantage, Cellini ordered his history to mirror a common dream and occasional reality of his age: the accomplished man of infinite versatility.

In her Life, Teresa quoted a religious writer who likened convents to "courts for the instruction of those who wish to be courtiers of heaven" (p. 282). Earlier she had visited an aristocratic house under her superior's command, where she found that "the comfort of the house was a real torture, and the great fuss that was made of [her] filled [her] with fear" (p. 250). She was not one to be impressed by a lady's favours: "I never treated those ladies, whom it would have been a great honour to serve, otherwise than with the freedom of an equal" (ibid.). She likened the life of a worldly courtier to slavery and had a hint of its cost in the envy of those who resented the lady's love for her. What distressed her most was the careful conduct required to avoid offending anyone's vanity: "For try though I might to please, I could not help making mistakes; and these, as I have said, are not passed over in the world" (p. 281). Worldly fashions and etiquette were all of a piece to her, and no values to live by.

Rather, she saw herself enjoying another kind of courtly existence, where the will rather than words was regarded, where the "kingdom is not hedged about by trifles" and no "third party" is needed to approach "His Majesty" (p. 279). For though that was her most common title in addressing 
God, she affirmed, "We can talk and converse with You about anything" (p. 280). Teresa delineated in her forms of address the full range of relationships accommodated in the one Majesty she served: "Lord," "Father," "Friend," "Captain" - even "Bridegroom," the object of intimate love-talk. There are two main strands of feeling in her relationship with her Lord, both of which were to develop important practical consequences in her world.

First, there is the intimate bond that led her to describe prayer as "a friendly intercourse and frequent solitary conversation with Him, who, as we know, loves us" (p. 63). Prayer began as work to "rise above the pain of being so much in the company of One who is so different from you" (ibid.). Prayer became enjoyment, for in these later stages "the labour is accompanied by so much bliss and comfort to the soul that the soul would never willingly abandon it" (p. 122). She never asked for consolations or favours, however, except once, and then she rapidly regretted doing so. Her reason is that she felt unworthy of them, and even the casual reader is struck by her continual confessions of wretchedness, which seem excessive. Unlike Cellini, who was a hedonist at heart - not a fact to scorn in itself - Teresa really felt more at home with pain than with pleasure. That may have been partly a temperamental preference, partly a response to the spiritual climate of her time; it almost certainly reflected a desire to share her Lord's suffering. As she put it, "Come what may, the great thing is to embrace the Cross. The Lord was deprived of all consolation, and forsaken in His trials. Let us not forsake Him" (p. 157). This compassion was to lead to spiritual union, described as "two separate things becom[ing] one" (p. 123). She also gave a more sophisticated account which would have delighted Pico della Mirandola. The soul, she explained, became like a mirror "entirely shaped to this same Lord, by a most loving communion" (p. 308).

It was an astonishing claim: the woman courtier (a category hotly debated in the third book of Castiglione's Il Corteggiano) had been raised from the ranks through betrothal and become in her words "mistress of everything" (p. 144). It is interesting to consider the use Teresa made of her "influence," remembering Cellini's repeated mishaps at the hands of offended royal consorts. Praying for favours on behalf of Father Garcia de Toledo, she twisted her Lord's hand: "You must not refuse me this favour. Think what a good man he is for us to have as a friend" (p. 252). Her solitude and solicitude expanded to embrace other potential courtiers, and in fact her book could be seen as a complement to Castiglione, especially in view of Pietro Bembo's speech in the fourth and last book of Il Corteggiano. Teresa 
laid out her reason for writing her Life as follows: "[W] hile my first intention in writing is to obey, my chief aim is to lure souls towards this sublime blessing" (p. 124).

At this juncture, it is worth examining a point made by Mary G. Mason in "Autobiographies of Women Writers,"6 a study that contains many valuable insights. She considers Teresa's Life together with that of other secular and religious women and draws the conclusion that "the self-discovery of female identity seems to acknowledge the real presence and recognition of another consciousness, and the disclosure of female self is linked to the identification of some 'other"' (p. 210). This would appear a useful insight when we consider the apparently opposing forms of Cellini's and Teresa's approaches to the self. Cellini stands out as the sole protagonist in his dramatic history of himself, while Teresa's life might finally appear to be merely an illustrative example in a spiritual guidebook of God's dealings with the soul. In fact, this view will be considered in the final section of this study. Yet an objection that might be raised here to Mason's thesis of sexual polarisation is the example of Augustine, whose statement in his Confessions of the "God-shaped void" in the human soul and its longing for "feminine" fulfillment is at least as strong as the "masculine" struggle that Mason emphasizes. Another objection presents itself in the example of Augustine's disciple Teresa. We must now consider the second dominant strand of her sense of soul.

"As for courage, they say that mine is far from slight, and it is well known that God gave me more than a woman's share of it" (p. 64) - or so Teresa claimed. The intimate side of Teresa has already been considered; here we see another Teresa. She described her kind in the third person: "They are like soldiers who wage wars in order to win booty and become rich; they know that they can never be rich without fighting. Trials are their profession" (p. 256). Her encounters began at home in her warring faculties. Spiritual favours, when they descended, were a new source of anxiety. In the tense climate of the Spanish Inquisition, where private revelations were distrusted and discouraged by the Catholic church and where numerous religious women had been discredited and exposed, Teresa suffered a long anguish of uncertainty about the source of her visions. That anguish of uncertainty is matched only by Bunyan's experience, from the opposite camp, as recorded in Grace Abounding. Her spiritual environment explains her distrust of consolations offered in ecstasies and her preference for the way of the Cross. There at least she knew that she was on the right road. Augustine's enemy 
was well-defined. For a long time Teresa was fighting against both God and the devil, with only her own weariness to fall back on.

What she seemed to have gained from remaining in the fray was a personal encounter that caused her inner divisions to be integrated at a point beyond herself. The martial element dates from this integration. A new sureness of tone emerges, together with a self-forgetfulness. One sees this in the way she handled opposition to her first commission in founding Saint Joseph's: "I saw quite well that in many respects my opponents were right. . . . But I could not tell them my principal argument - that I had been obeying the Lord's commands" (p. 241). She spoke metaphorically of a "captain" prized by God and entrusted with a company. She spoke of "great exploits" to be achieved with the favour of God, and one is led to liken her spiritual pain and renewal to those of a squire winning his spurs and fighting under a banner. Perhaps her early love of chivalric romance was not as irrelevant as she had thought.

Saint Joseph is an unusual patron in the conventual tradition, but the choice signified Teresa's manly soul. Like Cellini, she saw herself as a guardian of fortresses, although that, too, was only one facet of a versatile personality. The fortress of Saint Joseph's was also the garden paradise of "those who wish[ed] to enjoy the company of their Bridegroom, Christ, in solitude" (p. 276). Teresa was in a significant sense neither male nor female but a new creation. In her foundation, as in her book, she possessed parallel accomplishments to the arms and letters figured in Castiglione's courtier.

\section{Retelling Two Lives: Surprising Inversions}

\section{i) The Saint}

"The more I sought for rest, the more my tribulations increased" (p. 281) so ran the complaint of Cellini as he approached old age. From his earliest youth, his life had presented itself as a series of trials and stumbling blocks caused by the malice, envy and ingratitude of acquaintances, courtiers and patrons. Even his bosom friends had raised their heels against him. Whether it was Giovanni Caddi, who wished his death in order to seize his fortune, or "Rosso" - in Cellini's words, "the best friend I could have in the world" - who rewarded his generous treatment with "brazen-faced ingratitude" ( $p$. 182), the pattern of betrayal did not change. But through it all, Cellini seemed to have led a charmed life.

It began with his father's prophecies concerning him. When he was sentenced to death in Florence for attempted murder, his father, who had a 
previous history of prophetic utterance, mocked the magistrates: "You will do what God wills and nothing more" (p. 38); Cellini's escape confirmed this claim. More than once in his life, Cellini was to thank God for "averting the eyes" of his pursuers. And against the injustice of his foes, he was to assert the Almighty's intervention on his behalf, as the death of Luigi Pulci in the manner of his oath had demonstrated. But Cellini did not only wait for God's judgement to descend; he was ready to execute it. "God, who is always on the side of right, and I, who know how to assert it, will show you what a great mistake you've made" (p. 285), he told Francesco Bologna. Not even the Pope was exempt from Cellini's invocation of God's wrath, and in this he discovered a prophetic role like that of the Baptist against the Pharisees. He was less harsh in special cases: "I want to observe the decrees of our Holy Mother Church: although she is doing me this wicked wrong [imprisoning him], I am only too glad to forgive" (p. 214).

With the burden of prophecy came the visionary gift. Thus he was the only one to understand the portent of the beam of fire hovering over Florentine skies. When his predictions proved true about the murder of Duke Alessandro, they marvelled at him: "It's not worth spending money on couriers when you know things before they happen. What supernatural voice tells them to you?" (p. 166). In his illness, his second sight perceived the Enemy that hunted his soul in the form of a sinister old man. Such signs were, however, only the prelude to the grand vision of his prison experience, whereby he was to make sense of the significance of his sufferings and his commission. Troubled as to why God had suffered him to be imprisoned and prevented his attempted suicide by an overpowering hand, he "besought Christ to grant [him] at least the grace to know by divine inspiration for what sin [he] was doing such great penance" (p. 223). The answer came swiftly, as he was "seized by [an] invisible force and carried away as if by a wind" (p. 223). Ascending Jacob's "staircase," he was to see a vision of the sun's disc with a bulge in the middle, which became the crucifix. From thence, every doubt was vanquished.

There were, in fact, two answers. The New Testament answer ran that the "glorious divine Saviour [was] making [him] one with his disciples and friends, who like Him were killed unjustly" (p. 214). This is the substance of the Passion play. And so he played the part, in a manner worthy of a John of the Cross: "[A]11 day long I sang psalms and compositions of my own, all addressed to Him. ... Oh, how much happier I am now than I was then" (p. 219). The Old Testament answer was bound up with the image of the pilgrim 
Patriarch. Such figures, too, found trouble in the world, but this was also the surety of God's favour. Thus Cellini also responded: "God in his greatness has made me worthy to set eyes on His glory; on things perhaps never seen before by mortal eyes. So this proves my freedom, and my happiness, and my favour with God: while you villains, you shall always be villains, unhappy and in disgrace with God" (p. 224). In this role, it is permissible and indeed exemplary to wrestle for God's blessing. So we see Jacob "Perseus" Cellini in the casting of the Medusa-slayer wrestling for such a blessing. He would "vanquish all [his] perfidious enemies" (p. 333) if God gave him grace to create the bronze statue. In fact, he would have to win his blessing. Confronted with a death-dealing fever, the sabotage of enemies, the incompetence of workman and the resistance of Nature, he staged a remarkable comeback that worsted all opposition. In the irrepressible burst of energy involved in resuscitating the "corpse" of the Perseus, Cellini also brought himself back from death's door. A miracle of resurrection had been wrested, and Cellini was to relish his enemies' contention that he was obviously a fiend and no human being. The same had been said of his Lord before him.

Doubting Thomases, who refuse to believe that Cellini took his faith seriously, will cast a stone at his homicidal exploits or his sexual deviance, which are by no means venial sins. Cellini would in turn direct them to cast it at his stars, the malign conjunction of which he never ceased to deplore in medieval fashion: "So in a furious temper, swelling up like an asp, I made up my mind to do something desperate. This just shows how the stars completely rule rather than merely influence our lives" (p. 37). Art historians who deplore this treatment of Cellini's Mannerist career may consider that along with the Perseus, which he left as a symbol of his work, he left another in the marble crucifix he was so proud of. Two-thirds of the way into his autobiography, he wrote: "There is no motive of worldliness in my writing down these affairs of mine; all I want to do is give thanks to God for rescuing me from so many great afflictions" (p. 311). That might be considered with the worldly reason he gave on the first page for a more complete survey of his life. Alongside the Renaissance model of the "magnanimous man" who left his records for emulation stands the "Christian saint" who made his boast in the Lord.

ii) The Humanist

After running down the autobiography of Margery Kempe, a medieval religious, for its supposed failure to "relate meaningfully outer event and 
inner experience," Roy Pascal rather incomprehensibly praises Teresa for the way she "entwines the story of her inward experience with that of the small encounters of outward life." "What he assumes without explicitly saying is that Teresa as a Renaissance figure is in some way superior in self-awareness to the mystics of the Middle Ages.

Pascal's choice of examples is rather unfortunate, however. Not only is The Book of Margery Kempe (c. 1432) the first full English autobiography, as Mason points out, ${ }^{8}$ but it is probably among the first records of an active and contemplative lifestyle lived in conjunction. Margery, who had borne fourteen children, discovered a new husband in Christ and went about on pilgrimages to visit holy sites, to discuss her experiences, and to bear witness. The vicissitudes of her journeys, down to their domestic complications and her inconvenient gift of expressing compassion with Christ in uncontrollable weepings and howlings, are related with a unity of sense and feeling derived from her mystical commitment. Some of this appears bizarre, no doubt, and one might say that Margery was a singularly idiosyncratic character, but one could not accuse her of being a faceless figure or lacking a sense of self. Her confrontation with shocked and envious priests and parishioners could not have been sustained without a large measure of panache. In that respect, as in its journey motif, her autobiography yields interesting comparisons with Cellini's.

Pascal's comparison is unfortunate because, unlike Teresa, whose active life began late and who trampled down worldly detail with "manly strength," Margery never left it, and it was she who really "entwined the story of her inward experience with that of the small encounters of outward life." But the bringing together of the two characters is felicitous in another way. It allows one to see that before the Renaissance had magnified Man, the medieval mystics were already "publishing" their idiosyncratic lives and private reflections as if they had a right to do so.

Renaissance humanism has been perceived as a cultural and scholarly change in focus from abstruse theorising about the world, created and "increate" in the terms of medieval metaphysics, to the potential and responsibilities of Man reflected through the revived interest in moral and political philosophy. ${ }^{9}$ Humanism formed the substance of that "renewed faith in the power and stature of the human creature" 10 which is supposed to be the manifesto of the Renaissance. Yet the humanists themselves were aware of the negative side of human nature, and the interest in and study of Man initiated by Petrarch, Erasmus, More and Castiglione would lead to the dark 
formulations of Luther, Calvin, and Machiavelli, as well as to the scepticism of Montaigne, all of which ought to be considered part of the Renaissance proper and not, as Hiram Haydn suggests, a counter-culture. ${ }^{11}$

If we consider how Teresa stood in relation to these generalisations about the Renaissance and medieval mysticism, we can gain some sense of her part in both. First, we know from her Life that reading formed a major part of her contemplative career and that her diet consisted of the lives of other saints, which included the writings of the medieval mystics. We also know that she had little knowledge of scholastic philosophy and its distinctions; thus she confessed, "I am unable to use the proper terms and I cannot understand what is meant by 'mind' or how this differs from 'soul' or 'spirit.' They all seem the same to me, though the soul sometimes issues from itself, like a fire that is burning and has become wholly flame" (p. 122). We can see from this remark how she has substituted for scholastic logic "the poetry of experience." 12 In fact, although she could have had no formal training in rhetoric, Teresa's powers of organisation and expression are evident in her writing. She rediscovers the dynamic of the parable in the story of the peasant who died of shock through having uncovered a priceless treasure - a vivid illustration of the fact that God in his care bestows favours gradually - and the myth of the phoenix rising from its ashes, used as a metaphor for the old man dying into the new (p. 304).

The parable is itself a vehicle that draws from and communicates through individual and collective experience, conscious and unconscious, and is really the language of folk culture. ${ }^{13}$ So that if one thinks of the humanists as constituting a high culture against the scholastics, one might equally regard Teresa as their counterpart in a humbler mode. They drew on the classics of antiquity and she on the medieval mystics, amongst whom the tradition of devotion, which emphasized the individual's motive and response, and of experiential eloquence had never been lost. A good example is the most famous allegory in the writings of Dame Julian of Norwich:

Also in this he showed a littil thing, the quantitye of an hesil nutt in the palme of my hand; and it was as round as a balle. I lokid thereupon with eye of my understondyng and thowte: "What may this be?" And it was generally answered thus: "It is all that is made." I mervellid how it might lesten, for methowte it might suddenly have fallen to nowte for littil. And I was answered in my understondyng: "It lesteth and ever shall, for God loveth it; and so allthing hath the being be the love of God."14

In the form of an internal dialogue, which makes an interesting comparison with Plato's, the writer works with her spiritual understanding upon a 
visionary symbol and discovers to her amazement that she could hold all creation within the tiny hazel nut. The lesson she draws, which tells us as much about her as about her God ${ }^{15}$ - namely, that the seeming insignificance but truly infinite value of all creation, including herself, resides in her Creator's love - makes an interesting contrast to the Aristotelian methods of Aquinas, for instance, which leave out the aspect of personal relationship.

In fact, Dame Julian, Teresa and the humanists mentioned all share a common tradition, which has at its core a Son of Man who claimed also to be the Son of God and proffered that spiritual adoption to all who believed in that relationship. He preferred to speak in parables but allowed the methods of classical philosophy to elucidate and embellish the Christian faith. The mystic might be said to keep alive the dynamic of his personality and the claim that he is in Himself, "the Way, the Truth and the Life."

Teresa herself refused to lay aside the humanity of Christ in contemplation, insisting on its coherence with his divinity and refuting the "negative theology" of pseudo-Dionysius the Areopagite and others in his tradition. Her specific contribution as a Renaissance figure is her imaginative recovery of a whole range of positive human roles for the divine and for herself, a point that has been made in considering her life as a courtier. Further, in reading her Life, one is struck by the intensity with which she affirmed both sides of a dialectic that made up the Renaissance. In her battle-cry for the conquest of spiritual merit, one seems to hear an echo of Pico's great Oration, which gave to man "the power, out of [his] soul's judgment, to be reborn into the higher forms, which are divine." 16 Alternately, when she sinks into shame and self-abasement over her human weakness, one hears the plaintive notes of Luther.

The experience of both those sides of the spiritual equation is by no means novel; neither is the resolution of them. The above citation from Dame Julian expresses it, and Richard Hooker was to arrive at it in his sensible, rational way. It is the intensity of emotional immediacy in Teresa's statements that is novel - as if she had internalised the contradictions of her age and, suffering its anguish intimately, emerged on the other side without becoming crippled. That conflict is revealed in her vivid coupling of metaphors: "[T]here is no soul on this path who is such a giant that he does not often need to turn back and be a child at the breast again.... the questions of sin and self-knowledge are the bread which we must eat with even the most delicate dish on this road of prayer" (p. 94). Her chosen vocation was 
prayer, but she allowed that there were many roads to the Mansion of many rooms (p. 93). Perhaps one might allow that even the road of prayer, trodden with integrity, could present an inquiry into the spirit of Man that preoccupied the Renaissance. That Teresa was deficient in classical learning and the accomplishments of the secular life ought no longer, perhaps, to exclude her from our reckoning of Renascent selves.

Conversely, the checkered life of a flamboyant artist like Cellini may be presented with so much conviction of its spiritual character as to defy easy cynicism. The uneasy balance of sanctity and honour in Renaissance conceptions and projections of self is a familiar problem for the critic. The sprezattura of Castiglione's ideal courtier encompasses his martial, artistic and courtly prowess, even as it accommodates the Neoplatonic vision of love's sublimation such as we find it in Bembo's impassioned discourse in Il Corteggiano. Cellini's odyssey through the challenges of his craft and his career, where he is swift to defend his honour with the stiletto and "the sword of his mouth," is complemented by his discovery of a religious pattern, in which he discerned the hand of God moulding its object. Teresa, with her acute perception of the deceitful heart and her loathing of the false honour promoted by earthly courts, clearly defined the uncompromising pursuit of sanctity. Cellini retained the perspective of many Renaissance humanists, for whom sanctity remained the ideal completion of a life that had fulfilled its potential in the world. For Cellini, as for the patriarch Jacob, the ladder reached from earth to heaven and God was at the top. The crookedness of Jacob did not exclude him from heavenly visions, as he wrestled for a blessing, and it did not stop Cellini from interpreting his trials from a religious perspective.

The study of these two autobiographies gives us a glimpse of a sixteenth-century Europe where a man and a woman struggled with the fact that they were living spirits encased in flesh with a destiny to fulfill between heaven and earth. Though the Renaissance is popularly understood in terms of the rebirth of classical learning and the humanist impulses so fostered, one should perhaps also regard the wrestling with its Christian heritage as what gives the age its singular depth and distinction.

National University of Singapore 


\section{Notes}

1. Benvenuto Cellini, Autobiography, trans. George Bull (London: Penguin, 1956), p. 15. All quotations of Cellini are taken from this edition.

2. Saint Teresa of Ávila, The Life of Saint Teresa of Ávila by Herself, trans. J. M. Cohen (London: Penguin, 1957), p. 75. All quotations of Teresa are taken from this edition.

3. Roy Pascal, Design and Truth in Autobiography (London: Routledge, 1960), p. 1.

4. Robert T. Petersson, The Art of Ecstasy: Teresa, Bernini, and Crashaw (London: Routledge, 1970), p. 26.

5. Ibid.

6. Mary G. Mason, "The Other Voice: Autobiographies of Women Writers," in Autobiography: Essays Theoretical and Critical, ed. James Olney (Princeton, NJ: Princeton University Press, 1980), pp. 207-35.

7. Pascal, pp. 25-27.

8. Mason, p. 209. I should acknowledge my debt to Mason's insights on and placing of Julian of Norwich and Margery Kempe.

9. Cf. Isabel Rivers, Classical and Christian Ideas in English Renaissance Poetry (London: Allen and Unwin, 1979), pp. 132-47.

10. A phrase used by William Rose Benét, ed., The Reader's Encyclopaedia, 3rd ed. (London: Black, 1987). See entry on "Pico della Mirandola."

11. See Hiram Collins Haydn, The Counter-Renaissance (1950; rpt. Gloucester, MA: Peter Smith, 1966).

12. A phrase used by Robert Langbaum (The Poetry of Experience: The Dramatic Monologue in Modern Literary Tradition [London: Chatto and Windus, 1957]).

13. My views on this point have been generally influenced by Carl Jung and Northrop Frye.

14. Julian of Norwich, A Revelation of Love, ed. Marion Glasscoe (Exeter: University of Exeter, 1976), p. 5.

15. I do not mean that the internal dialogue is generated by her own psychological state, supposing the vision to be real. I mean that the questions a person asks and his interpretation of an answer reflect on the person he/she is.

16. Giovanni Pico della Mirandola, "Oration on the Dignity of Man," trans. Elizabeth Livermore Forbes, in The Renaissance Philosophy of Man, ed. Ernst Cassirer et al. (Chicago: University of Chicago Press, 1948), p. 225. 